\title{
INTERNAL RESTRICTIONS CONCERNING FREEDOM OF MAKING DECISIONS BY OFFICERS IN POLISH ARMED FORCES
}

\author{
Zbigniew REDZIAK \\ National Defence University, Warsaw, Poland \\ z.redziak@aon.edu.pl
}

\begin{abstract}
This article presents selected aspects of internal restrictions relating to officers' making decisions at tactical level in the Land Forces of the Polish Armed Forces. It is dedicated to military practitioners and theoreticians who deal with command and control. The article includes the following kinds of decision-making restrictions: pressure from superiors, capital restrictions, time pressure, structural limitations and cultural restrictions.
\end{abstract}

Keywords: decision-making, military, restrictions.

\section{Introduction}

As it appears from experiences collected during military operations, one of the toughest problems that land commanders face is the decision-making. They should be able to deal with this kind of a problem. However, no matter how good the decision making process is, commanders cannot eliminate all freedom restrictions regarding making decisions although they are duty bound to avoid or minimize negative influence of these limitations.

The results of theoretical researches [1] show that commanders (decision makers) face many restrictions. These can result from different threats connected with military organisations. Moreover, in a large part these restrictions are related to internal weak points. It is worth remembering that all restrictions concerning freedom of making decisions can be normative (procedural), social or they can be connected with resources.

2. Internal factors restricting military decision-making freedom on tactical level - results of empirical research

The results of empirical research carried out on a group of officers in the Land Forces of the Polish Armed Forces (picture 1) show that decision-making freedom can be restricted by the following internal factors [2]:

1. Pressure from superiors.

2. Capital restrictions.

3. Time pressure.

4. Structural limitations.

5. Cultural retrictions. 


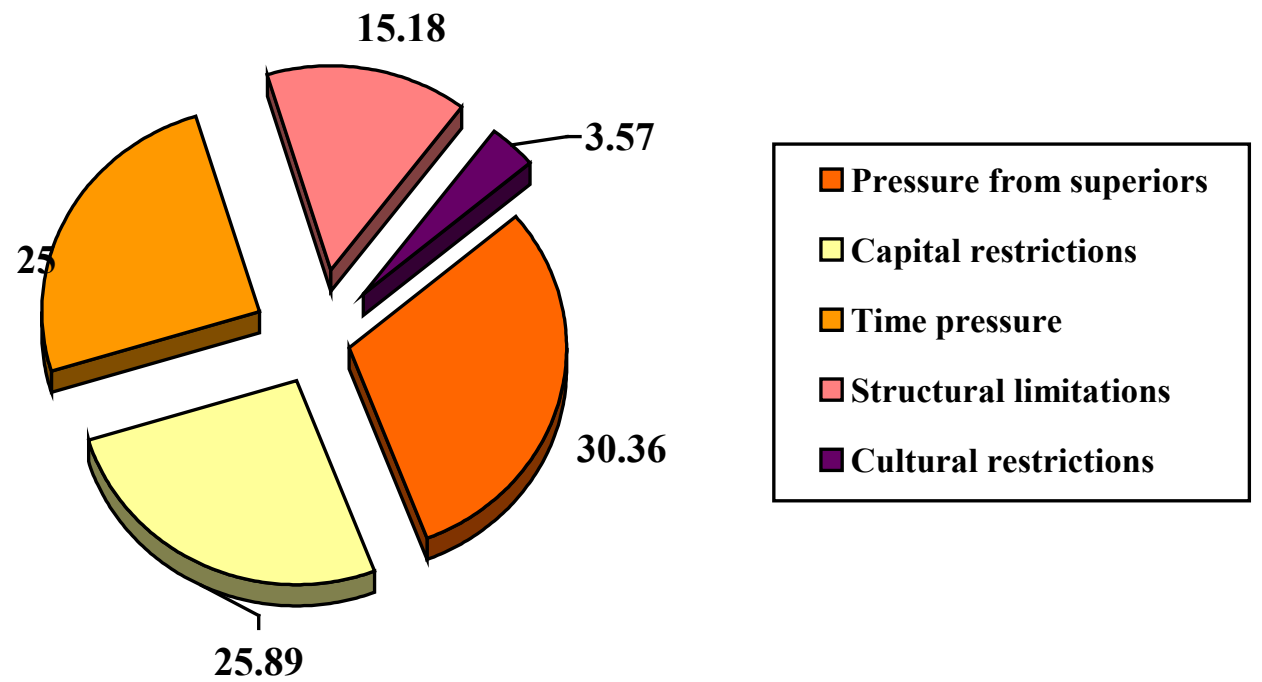

Figure 1: The importance of factors restricting decision-making freedom on tactical level in the Land Forces of the Polish Armed Forces according to tested officers

The question that respondents were asked was: In your opinion, how important is each of these internal factors restricting commanders' decision-making freedom? The answers, in order of importance, were as follows: $30,36 \%$ of respondents decided that the most important factor was pressure from superiors, $25,89 \%$ - that these were capital restrictions, $25 \%$ pointed time pressure, $15,18 \%$ - structural limitations and finally $3,57 \%$ - cultural restrictions.

As far as pressure from superiors is concerned, its importance and influence on decision-making freedom can result in choices different than one's intent. This factor can discourage subordinates from making decisions even when there are more benefits than risks, or they can be forced to make high-risk decisions when there are hardly any benefits. In extreme cases it can lead to depriving subordinates of freedom. As a result, they might lose their motivation and their effectiveness can decline. In addition, there might be fewer initiatives and underlings' creativity might deteriorate.

\section{As for capital restrictions}

(of resources), they are caused by shortage of different kinds of resources: personal, financial, informational and material. All these resources are necessary for planning, organizing and carrying out actions. Lack of any of these resources or of information makes it impossible for commanders to make a decision or put it into practice. The above-mentioned restrictions preclude making the right use of strengths and opportunities, as well as counteracting weaknesses and identified threats.

As far as time pressure is concerned, its importance was similar to that of capital restrictions. It can restrict rightness of making decisions by commanders and staff in case of:

1. Shortage of time needed in order to gather information about enemy, one's own troops and fighting area.

2. The need to solve a few decisionmaking problems at the same time.

3. Making it difficult to analyse information and shortening the amount of time necessary to prepare and consider different options of actions.

4. Shortening time for organizing actions and in particular their synchronisation.

5. Spending too much time carrying out actions (concerns one's own troops).

6. Causing stress which in turn might result in the detriment of one's own health as well as irrational decisions.

Structural limitations, to be more precise division of power in an organisation, are the next internal factor which influences freedom of making 
decisions. Both one's scope of responsibility and range of commanding powers depend on his or her position within a given structure. This in turn is connected decision-making freedom and the more powers, the more freedom when making decisions, and inversely.

Structural limitations have influence on decision-making freedom as:

1.They generate vertical and horizontal communities of interests and aims within one's own troops.

2. They define rules of superiority and subordination as well as functional relationships. In other words, structural limitations define correlations between superiors, subordinates etc.

3.They are used to distribute personal, financial, material and informational resources.

4.They impose different demands on decision makers depending on their level of command.

5.They impose preferred style of commanding.

Finally, cultural restrictions result from dominant, unseen and often unknown assumptions whose reflection can be seen in universally accepted standards and values. They are manifested through one's opinions and attitudes.
These restrictions are closely connected with culture of a given organisation, i.e. a specific collection of values, model behaviours, attitudes, beliefs, myths, symbols, rituals, ceremonials and many other rules recorded in people's memory and imagination. They are passed on succeeding generations of soldiers.

Although cultural restrictions are not usually reflected in formal documents, they limit commanders' freedom of actions. When cultural norms are broken, as a result informal sanctions are inflicted (e.g. rejection, victimization or ostracizm). However, according to officers who took part in the survey cultural restrictions are not important for commanders' decisionmaking. This opinion might be a result of strongly formalized structure of the army or lack of knowledge concerning this subject.

Since pressure from superiors was chosen as the main factor restricting commanders' freedom when making decisions, more details are presented in chart 1. The following independent variables were taken into account: military rank, military service, post and participation in military missions abroad.

Chart 1: Percentage results of pressure as a factor restricting commanders' (supervisors') freedom of making decisions versus independent variables

\begin{tabular}{|c|c|c|c|c|c|}
\hline \multirow[b]{2}{*}{ Variables } & \multicolumn{5}{|c|}{$\begin{array}{l}\text { The importance of superiors' pressure as a factor restricting } \\
\text { decision-making freedom }\end{array}$} \\
\hline & $\begin{array}{c}\text { The } \\
\text { highest } \\
\text { rank }\end{array}$ & $\begin{array}{l}\text { High } \\
\text { rank }\end{array}$ & Middle rank & $\begin{array}{l}\text { Low } \\
\text { rank }\end{array}$ & $\begin{array}{c}\text { The lowest } \\
\text { rank }\end{array}$ \\
\hline \multicolumn{6}{|c|}{ Military rank } \\
\hline Senior officers & $47,17 \%$ & $15,09 \%$ & $11,32 \%$ & $18,87 \%$ & $7,55 \%$ \\
\hline Junior officers & $47,46 \%$ & $22,03 \%$ & $13,56 \%$ & $10,17 \%$ & $6,78 \%$ \\
\hline \multicolumn{6}{|c|}{ Military service } \\
\hline $1-10$ years & $59,26 \%$ & $18,52 \%$ & $14,81 \%$ & $7,41 \%$ & $0,00 \%$ \\
\hline $11-20$ years & $42,55 \%$ & $25,53 \%$ & $8,51 \%$ & $8,51 \%$ & $14,89 \%$ \\
\hline 21 and more years & $44,74 \%$ & $10,53 \%$ & $15,79 \%$ & $26,32 \%$ & $2,63 \%$ \\
\hline \multicolumn{6}{|c|}{ Post } \\
\hline Command & $42,86 \%$ & $20,00 \%$ & $14,29 \%$ & $20,00 \%$ & $2,86 \%$ \\
\hline Staff & $49,35 \%$ & $18,18 \%$ & $11,69 \%$ & $11,69 \%$ & $9,09 \%$ \\
\hline \multicolumn{6}{|c|}{ Participation in military missions abroad } \\
\hline No experience & $47,76 \%$ & $17,91 \%$ & $16,42 \%$ & $14,93 \%$ & $2,99 \%$ \\
\hline Participated in missions & $46,67 \%$ & $20,00 \%$ & $6,67 \%$ & $13,33 \%$ & $13,33 \%$ \\
\hline
\end{tabular}


As shown in chart 1, pressure from superiors received the highest percentage number among officers with military service ranging from 1 to 10 years. However, the most experienced officers with 21 or more years of service in the army assigned the highest number of low ranks to pressure from superiors. Therefore it is likely that the longer the service, the less important pressure from superiors as factor restricting commanders' freedom when making decisions. In other words, with the passing of time officers become more innerdirected. Moreover, as often is the case, these results show discrepancy between the results of the research and common opinions concerning this matter as many believe that young soldiers are more likely to oppose to pressure from their superiors than their more experienced colleagues. Therefore it is advisable to conduct further research in order to verify the result presented above.

As far as staff officers are concerned, they indicated higher percentage of the highest ranks in terms of pressure from superiors on decision-making freedom than commanding officers. That may indicate that commanding officers are more assertive than staff officers.

As for soldiers who did and did not take part in military missions abroad, there are only minor differences concerning assignment of the highest ranks. However, there is a significant discrepancy with reference to assigning the lowest ranks. Officers participating in military missions abroad are more likely to ignore pressure from their superiors. Therefore it can be concluded that they are more assertive when making decisions than officers with no experience in military missions abroad.

\section{Conclusions}

To sum up, there are many internal factors beyond commanders' control. Consequently, officers face many dilemmas concerning decision-making. Moreover, this limits their decision-making freedom. In addition, commanders experience constant pressure from their superiors. Finally, when making decisions officers need to take into account time pressure, capital restrictions, as well as structural limitations and cultural restrictions.

However, in spite of all the restrictions mentioned above commanders do make the right decisions because of their knowledge, operating imagination as well as experience and ability to take risks, even in conditions that extremely restrict their decision-making freedom.

\section{References}

[1] Compare: J. Wołejszo, R. Jakubczak (ed.), Obronność. Teoria i praktyka (Defence. Theory and Practice), Bellona, Warszawa 2013; Planowanie działań na szczeblu taktycznym w wojskach ladowych (Operation Planning on Tactical Level in Land Forces), DD/3.2.5, DWLąd Wewn. 96/2007, Warszawa 2007; K. Bolesta-Kukułka, Decyzje menedżerskie (Manageral Decisions), PWE, Warsaw 2003; J. Kręcikij, J. Wołejszo (ed.), Podstawy dowodzenia (Fundamentals of Command and Control), AON, Warszawa 2007; T. Tyszka, Decyzje. Perspektywa psychologiczna i ekonomiczna (Decisions. Psychological and Economic Perspective), Scholar, Warszawa 2010.

[2] See: Z. Redziak, Podejmowanie decyzji w warunkach ryzyka (Decision-Making under Risk Conditions), AON, Warszawa 2009, pp. 56-63; Z. Redziak, Podstawy teorii podejmowania decyzji (Fundamentals of Decison-Making Theory), AON, Warszawa 2013, pp. 28-34. 